www.jmscr.igmpublication.org

Index Copernicus Value: 79.54

ISSN (e)-2347-176x ISSN (p) 2455-0450

crossrefDOI: https://dx.doi.org/10.18535/jmscr/v7i2.47

\title{
Placental histopathology in full term low birth weight new born babies in a tertiary care centre
}

\author{
Authors \\ P. Magesh ${ }^{1}$, D. Sheeba ${ }^{2 *}$, S. Ravi ${ }^{3}$, Subashini $S^{4}$, Dhanya Varghese ${ }^{5}$ \\ Chengalpattu Medical College, India \\ *Corresponding Author
}

D. Sheeba

\begin{abstract}
Background: Placenta is a vital structure for fetomaternal circulation and it is directly related to growth and development of the fetus. Placental examination, provides important information regarding maternal complications, perinatal fetal death, perinatal fetal diagnosis and multiple pregnancies. Placental changes like infarct, syncytitial knots, fibrinoid necrosis, basement membrane thickening are associated with retarded growth of the new born.

Materials and Methods: Fifty freshly delivered placenta of full term low birth weight babies were examined for gross features and histomorphological features. Gross findings like weight of the placenta, attachment of cord, diameter, volume and shape of placenta were noted. Placental changes like infarct, calcification, syncytitial knots, fibrinoid necrosis, basement membrane thickening are associated with retarded growth of the new born also been evaluated in comparison to other studies.

Results: Fifty placentas from full term low birth weight babies were studied. Most of the mothers are in the age group of 22-27 years with primi contributing to $74 \%$. Gross findings like marginal attachment of placenta contribute to $32 \%$, eccentric attachment in $12 \%$ cases were noted. Microscopic findings like fibrinoid necrosis(64\%), infarct(52\%), calcification(36\%), syncytial knots(76\%).

Conclusion: Histopathological study of placenta is reasonably simple technique in identifying the pathological findings contributing to the low birth weight in full term mothers in addition to the clinical exmination. Gross features like attachment of umbilical cord to placenta and microscopic findings like fibrinoid necrosis, infarct, calcification, syncytial knots strongly attribute to uteroplacental insufficiency in full term low birth new born when compared to other histomorpholgical studies in the literature.
\end{abstract}

\section{Introduction}

Placenta is a vital structure for foetomaternal circulation and it is directly related to growth and development of the fetus. ${ }^{(1)}$ Placenta is composed of lacuna, floating and anchoring villi, cytotrophoblast and syncytiotrophoblast, uterine blood vessels and uterine connective tissue ${ }^{(2)}$. Placental examination, an integral part of fetal and perinatal autopsy and provides important information regarding maternal complications, perinatal fetal death, perinatal fetal diagnosis and multiple pregnancies ${ }^{(3)}$. Premature aging of placenta was found to be important factor in determining fetal outcome despite maternal and fetal factors $^{(4)}$ Placental changes like infarct, syncytitial knots, fibrinoid necrosis, basement 
membrane thickening are associated with retarded growth of the new born ${ }^{(5)}$ Various maternal and fetal factors like nutritional deficiencies, anemia, alcoholism, genetic factors and multiple pregnancies are considered to be risk factors in full term low birth weight babies. ${ }^{(6)}$ Careful gross and histomorphological examination of the placenta may reveal pathology associated with full term low birth weight new born $(<2.5 \mathrm{~kg}$ birth weight).

\section{Aims and Objectives}

1. To study the morphological changes in the placentas of full term low birth weight mothers.

2. To evaluate the placental pathology that may contribute to low birth weight in full term pregnancies.

\section{Materials and Methods}

Fifty freshly delivered placenta of full term low birth weight babies were collected from the department of obstetrics and gynecology. Permission was taken from the institutional ethics committee and head of obstetrics and gynecology, study was done under MDRU project. History was collected from the mothers regarding age, parity, sex of the baby and gestational age. Placentas collected were washed under running tap water and cords along with membranes are examined grossly for any abnormalities. The placentas along with umbilical cords were placed in $10 \%$ neutral buffered formalin in wide mouthed containers and tagged with numbers for identification

On gross examination the following findings are noted as in table 1 .

After adequate fixation in formalin placenta was grossed and bits were taken from the representative sites.

Table 1: Gross examination findings

\begin{tabular}{|c|c|}
\hline S.NO & Gross parameters \\
\hline 1 & Shape, \\
\hline 2 & $\begin{array}{r}\text { Position of Umbilical cord } \\
\text { attachment }\end{array}$ \\
\hline 3 & Weight, \\
\hline 4 & Diameter and volume, \\
\hline 5 & Number of cotyledons. \\
\hline 6 & Areas of hemorrhage and necrosis \\
\hline
\end{tabular}

The slides are examined for following pathological findings:

1. Basement membrane thickening

2. Fibrinoid necrosis

3. Villous edema

4. Syncytial knots

5. Choriongiosis

6. Stromal calcification

7. Villous fibrosis

8. Villous hofbauer cells

\section{Methodology}

Study duration: July 2018 to Nov 2018.

Study type: Prospective observational study.

\section{Inclusion criteria}

1) Full term mothers, 36-40weeks with low birth weight new borns.

2) Singleton pregnancy.

\section{Exclusion criteria}

1) Multiple pregnancies

2) Mothers who delivered in preterm.

3) Pregnancy complicated by disorders

\section{Results}

In our study, 50 placentas of full term low birth weight babies with weight $<2.5 \mathrm{~kg}$ were studied. Age group of mothers range from 19-35 years, most of them are between 22-27 years of age with mean age being-24 years (table 2).

Table 2: Age distribution in our study

\begin{tabular}{|c|c|c|}
\hline Age group & No of cases & \% \\
\hline$<20 \mathrm{yr}$ & 1 & 2 \\
\hline $21-25$ & 38 & 76 \\
\hline $26-30$ & 9 & 18 \\
\hline$>30$ & 2 & 4 \\
\hline Total & 50 & 100 \\
\hline
\end{tabular}

In our study, most of the cases were primi contributing to 37 cases $(74 \%)$ and multipara contributing to 13 cases (26\%).

Table 3: Parity of patients

\begin{tabular}{|c|c|c|}
\hline Parity & No of cases & $\%$ \\
\hline Multi & 13 & 26 \\
\hline Primi & 37 & 74 \\
\hline Total & 50 & 100 \\
\hline
\end{tabular}

Most of the new born are in the group of weighing between $2-2.4 \mathrm{~kg}$ (47 cases) with mean weight of 
about $2.3 \mathrm{~kg}$. Only one new born contributes to weigh less than $2 \mathrm{~kg}$.

Most of the placenta in the study is discoid shape which differs in attachment of umbilical cord being marginal, central and eccentric. Most of the placenta has central attachment of cord (28 cases) and marginal 16 cases.

Average weight of the placenta in the study is 497 gm and most of the placenta was in between 501$600 \mathrm{gm}$. In our study average diameter of the placenta was $18.6 \mathrm{~cm}$ and most of the placentas have diameter in between $18-19 \mathrm{~cm}$. Average number of cotyledons in our study was found to be 17 cotyledons and total number of cotyledons in our study range from 10-23.Other gross findings like infarction and calcification are mentioned in the table below:

Table 5: Percentage of cases displaying infarction and calcification

\begin{tabular}{|l|c|c|}
\hline Gross findings & No of cases & Percentage \\
\hline Infarction & 26 & 52 \\
\hline calcification & 18 & 36 \\
\hline
\end{tabular}

Microscopic findings in our study are mentioned below in the table 6 .

Table 6: Microscopic examination findings in our study

\begin{tabular}{|l|c|c|}
\hline Microscopic findings & No. of cases & Percentage \% \\
\hline $\begin{array}{l}\text { Basement } \\
\text { membrane thickening }\end{array}$ & 31 & 62 \\
\hline Fibrinoid necrosis & 32 & 64 \\
\hline Villous edema & 30 & 60 \\
\hline Syncytial knots & 38 & 76 \\
\hline Choriongiosis & 10 & 20 \\
\hline Stromal calcification & 44 & 88 \\
\hline Villous fibrosis & 24 & 48 \\
\hline Villous hofbauer cells & 10 & 20 \\
\hline
\end{tabular}

\section{Discussion}

As placenta is essential for foetomaternal circulation, it is important to study placental pathology in cases of full term low birth weight babies. Intrauterine growth retardation is due to maternal, fetal and placental causes, but ultimate pathophysiology is secondary to uteroplacental blood flow and transfer of nutrients from mother to foetus. ${ }^{(7)}$ Placental pathology can contribute to reduced uteroplacental blood flow, thereby resulting in intrauterine growth retardation ${ }^{(8)}$. Low birth weight is defined as newborn with weight less than $2.5 \mathrm{~kg}$ at the time of birth $^{(9)}$. Placenta is essential for the normal growth of the fetus. Fetal growth retardation may be contributed by maternal, fetal and placental causes. In our study, we concentrated on placental pathology contributing to the low birth weight in full term new borns. Multiple placental lesion can contribute to retarded growth of the foetus ${ }^{(5)}$ The common factors observed to be uteroplacental insufficiency or reduced utero placental blood flow. In our study, 50 placentas from full term new born were studied.

Most of the placenta was from primi gravida in our study with average age of being 24 years. In our present study, average weight of the placenta was $497 \mathrm{gm}$, compared to study by Mardi K et al(10), placental weight was 300-400 gm.

In a study by Panti et al, placenta weight was found to be 300-400gm which was little lower than the present study ${ }^{(11)}$.

Attachment of umbilical cord to placenta like marginal, central and eccentric were noted in our study, Marginal and eccentric attachment was found to be $44 \%$, when compared to a study by Prabhjot et $\mathrm{al}^{(12)}$ study it was around $52 \%$. There is strong association between types of attachment of umbilical cord to placenta with infarction. $(\mathrm{P}<0.05)$ in our study in a univariate analysis. Placental thrombi and fibrinoid necrosis are commonly associated with the marginal and eccentric insertion of the umbilical cord to the placenta ${ }^{(13)}$.

In our study, placentas show high percentage of infarction(52\%) and calcification(36\%) when compared to studies by Mardi et al and Mehendale et $\mathrm{al}^{(10)}$ as shown in table 7 . In a study by Kleebkaow et al. placental infraction was observed in $30.4 \%$ of low birth weight babies ${ }^{(14)}$. Syncytial knots are secondary to chronic uteroplacental insufficiency which leads to reduced villous blood flow ultimately leads to low birth weight. In our study, syncytitial knots are seen in $76 \%$ cases, higher percentage when compared to Mirchandani et al and Bazaz et al studies ${ }^{(15)}$. Basement membrane thickening and fibrinoid necrosis are 
seen in $62 \%$ and $64 \%$ of cases respectively in our study. No evidence of chronic villitis is observed in our study, but study by Mardi K et al ${ }^{(10)}$.

Various microscopic findings like Basement membrane thickening, Fibrinoid necrosis, Villous edema, Syncytitial knots, Choriongiosis, Stromal calcification. Villous fibrosis, Villous hofbauer cells are attributed to chronic uteroplacental insufficiency and reduced villous blood flow.

\section{Conclusions}

Histopathological study of placenta is reasonably simple technique in identifying the pathological findings contributing to the low birth weight in full term mothers in addition to the clinical examination. It was found that, placental findings in our study ultimately point towards reduced uteroplacental blood flow and chronic uteroplacental insufficiency may be secondary to premature aging of placenta. Careful gross examination and microscopic examination of placenta of full term low birth weight babies will reveal a various pathological factors that would be underlying cause for low birth weight in full term babies. Microscopic findings like fibrinoid necrosis (64\%), infarct (52\%), calcification $(36 \%)$, syncytial knots $(76 \%)$ strongly suggests uteroplacental insufficiency in our study.

Table 7: Comparison of infarction and calcification with other studies.

\begin{tabular}{|l|c|c|c|}
\hline $\begin{array}{l}\text { Gross } \\
\text { lesion }\end{array}$ & $\begin{array}{c}\text { Present } \\
\text { study } \\
(\mathbf{\%})\end{array}$ & $\begin{array}{c}\text { Mardi } \\
\text { et al } \\
(\mathbf{\%})\end{array}$ & $\begin{array}{c}\text { Mehendal } \\
\text { et al } \\
(\mathbf{\%})\end{array}$ \\
\hline Infarction & 52 & 16 & 41 \\
\hline calcification & 36 & 28 & 35 \\
\hline Normal & 24 & 40 & - \\
\hline
\end{tabular}

\section{Acknowledgement}

We would like to acknowledge the Department of Obstetrics and Gynecology for extending the warm support through tout the study.

\section{References}

1. Gude NM, Roberts CT, Kalionis B, King RG. Growth and function of the normal human placenta. Thromb Res. 2004;114(5-6):397-407.

2. Avagliano L, Massa V, Bulfamante GP. Histology of Human Placenta. : 15 .
3. Tellefsen $\mathrm{CH}$, Vogt $\mathrm{C}$. How important is placental examination in cases of perinatal deaths? Pediatr Dev Pathol Off J Soc Pediatr Pathol Paediatr Pathol Soc. 2011 Apr;14(2):99104.

4. Placenta in intrauterine growth retardation. | POPLINE.org [Internet]. [cited 2019 Jan 8].

5. Placental pathology in low birth weight babies a prospective observational study. Indian $\mathbf{J}$ Pathol Oncol. 2018 May 30;5(2):178-83.

6. Singh G, Chouhan R, Sidhu K. Maternal Factors for Low Birth Weight Babies. Med J Armed Forces India. 2009 Jan;65(1):10-2.

7. Intrauterine growth restriction (IUGR): Symptoms, Causes, Diagnosis, Management, Complications \& Prevention [Internet]. AIMU. 2018 [cited 2019 Jan 30].

8. Placental Pathology in Intrauterine Growth Retardation. [Internet]. [cited 2019 Jan 30].

9. Prevalence and causes of low birth weight in India. - PubMed - NCBI [Internet]. [cited 2019 Jan 8].

10. Mardi K, Sharma J. Histopathological evaluation of placentas in IUGR pregnancies. Indian J Pathol Microbiol. 2003 Oct;46(4):5514.

11. Panti AA, Ekele BA, Nwobodo EI, Yakubu A. The relationship between the weight of the placenta and birth weight of the neonate in a Nigerian Hospital. Niger Med J J Niger Med Assoc. 2012 Apr;53(2):80-4.

12. 435.pdf [Internet]. [cited 2017 Jan 23].

13. (PDF) Insertion of Umbilical Cord on Placenta in Hypertensive Mother [Internet]. [cited 2019 Feb 1].

14. Kleebkaow P, Limdumrongchit W, Ratanasiri T, Komwilaisak R, Seejorn K. Prevalence of placental pathology in low birthweight infants. J Med Assoc Thail Chotmaihet Thangphaet. 2006 May;89(5):594-9.

15. Placenta in intrauterine growth retardation. | POPLINE.org [Internet]. [cited 2019 Jan 7]. 